\title{
ACRL Board of Directors' actions, February 2018
}

\section{Highlights of the Board's Midwinter meetings}

During the 2018 ALA Midwinter Meeting in Denver, the ACRL Board of Directors met on February 10 and February 12 . The Board met with the leaders of its four goal-area committees: New Roles and Changing Landscapes, Research and Scholarly Environment, Student Learning and Information Literacy, and Value of Academic Libraries to assess progress on the Plan for Excellence.

The Board also heard updates from ALA

\section{Plan for Excellence}

- The Board charged a working group to explore how ACRL could best demonstrate ACRL's commitment to equity, diversity, and inclusion (EDI). The Board asked for the
Treasurer Susan Hildreth and ALA CFO Mark Leon, the ALA Washington Office Associate Executive Director Kathi Kromer, as well as updates from representatives from the ACRL Diversity Alliance, ACRL Libraries Transform Implementation Task Force, Joint ACRL/LLAMA Interdivisional Committee on Building Resources, and ALA Council Committee on Legislation.

The ACRL Board of Directors took the following actions:

working group to develop an ACRL signature initiative supporting EDI and to develop proposed language to amend the ACRL Plan for Excellence to include and articulate the signature initiative.

\section{Enabling Programs and Services: Education}

- Approved the proposal to hold the 2023 ACRL Conference in Pittsburgh, Pennsylvania,
March 15-18, 2023, and the 2027 ACRL Conference in Portland, Oregon, April 7-10, 2027.

- Approved the 2019 ACRL Conference scholarship campaign goal of $\$ 50,000$.

\section{Enabling Programs and Services: Member Engagement}

- Approved the creation of the divisionlevel Systematic Reviews and Related Methods Interest Group.

- Received the final report from the Community College Engagement Task Force, thanked the Task Force for their work, and directed staff to create a marketing plan focused on increasing the number of community college librarians who are ACRL members and to offer assistance to CJCLS leaders in updating their communication tools and brand image.

\section{Enabling Programs and Services: Publications}

- Approved the revisions to the "Standards for Libraries in Higher Education."

- Approved the "Guidelines for Primary
Source Literacy" (which will also be reviewed and acted upon by the Society of American Archivists Council). 


\section{Enabling Programs and Services: Operations}

- Confirmed the virtual votes approving the minutes of the ACRL Board meetings at ALA Annual Conference 2017 and the minutes of the virtual ACRL Board of Directors Fall Meeting held on October 26, 2017.

- Confirmed the virtual vote approving to postpone indefinitely the proposed name change of the Value of Academic Libraries Committee.

- Amended the policy that the Executive Director is authorized to approve individual unbudgeted expenditures increasing the amount from $\$ 5,000$ to $\$ 10,000$ not to exceed $1 \%$ of the total ACRL and CHOICE budgeted expenses in a fiscal year. The Executive Director will notify the ACRL President of such expenditures.

- Approved up to $\$ 25,000$ to co-fund, with the ALA Development Office and other ALA divisions, a six-month prospect researcher.

- Approved a Statement on Vendor Relations that articulates ACRL's aim to engage with all stakeholders in establishing best practices that preserve the integrity of the association while benefiting members and stakeholders. $\not{z}$

("Frame by frame," continues from page 189)

knowledge practices they taught during the session. We found this level of granularity manageable to track for one frame, but anticipate that it will be difficult to assess for all the frames because the form will become too long. Because of this, our assessment committee is currently amending the library's assessment plan to make it simpler and less granular. Once this is finished, each frame will have two measurable learning outcomes we can use in our curriculum mapping, instead of trying to measure all the knowledge dispositions and practices.

During our Library Launch sessions, we had planned to test students on their use of the "peer-reviewed" check box in our discovery layer to check their understanding of the Authority frame. During instruction, students watched a video that defined peer-review and listed some of the markers of authority. In the class activity, we asked students to perform a search, limit to articles, then limit to "peer-reviewed" by checking a box. Most students in the Library Launch successfully limited to peer-reviewed journals, but then applied the concept inexpertly when choosing an article from the list of results.

Our data shows us that some students picked a nonscholarly article or review from within a peer-reviewed publication. In the future, we will walk students through an example of what a peer-reviewed article should look like, then ask them a question that more directly assesses their learning of "Authority is Constructed and Contextual." Through this summative assessment, we will be able to track student learning from year to year.

\section{Conclusion}

Our assessment efforts have yielded interesting and fruitful information on how we use the ACRL Framework at the Carl B. Ylvisaker Library. This has helped us in our plans to refine our forms for Reference and Instruction with the aim of collecting less granular data. We also plan to collect more data on how well students are applying the frames in library sessions by including an assessment on "Authority is Constructed and Contextual" in our Library Launch session. In spring of 2018 we will grade our first batch of Exemplary Research Award papers using an updated rubric, which will provide data on how well our best upperlevel students apply the ACRL Framework in their research and writing. Our longterm goal is to implement more assessments of student learning in our library sessions, and to incorporate these into a cohesive assessment plan. $\approx 2$ 